\title{
Comparative Analysis of the Changes in Cash Demand in Hungary*
}

\author{
Tamás Végső
}

The strong growth of cash in circulation in Hungary seen in recent years seemingly contradicts the changes in payment habits and can also be interpreted to show that the development of the Hungarian payment system is falling behind relative to other countries in Europe. Placing the Hungarian data in an international context, this study attempts to provide a true and accurate picture of the situation with cash usage in Hungary and uses the relevant literature to present the trends in cash demand observed globally. One important conclusion is that, in terms of their nature, transactional cash demand and cash demand for savings purposes are clearly separated, with the latter primarily responsible for the expansion of the volume of cash on a global scale. While the growth seen in Hungary may be high in European comparison, taking into consideration changes in interest rate levels and GDP it cannot be seen as extreme. Based on international trends, the realistic goal for Hungary should primarily be to decelerate the expansion, as experiences show that a nominal decrease in cash volume requires the long-term and concurrent existence of several factors.

Journal of Economic Literature (JEL) codes: D14, E41, E42, E58

Keywords: cash demand, cash-to-GDP ratio, payment habits, electronic payments, cash holdings, shadow economy, cashlessness

\section{Introduction}

Today, people in practically all countries around the world are experiencing a transformation of payment habits first hand. Hungary is no exception: one need only think of music festivals that have gone cashless or, for that matter, the fact that most street fairs now also accept card payments, and there are also churches where donation boxes have been replaced by card reader terminals. These phenomena are also confirmed by the Payment Systems Report (MNB 2019a) published by the Magyar Nemzeti Bank (MNB). In terms of the number of transactions and total value, bank card payments increased by approximately

* The papers in this issue contain the views of the authors which are not necessarily the same as the official views of the Magyar Nemzeti Bank.

Tamás Végső is a Cash Policy Expert at Magyar Nemzeti Bank.Email: vegsot@mnb.hu

The Hungarian manuscript was received on 16 September 2019.

DOI: http://doi.org/10.33893/FER.19.1.90118 
25 per cent in Hungary between 2017 and 2018, and today more than three quarters of transactions are conducted in stores that allow for electronic payment. Recent years have seen contactless cards gain ground at an explosive rate, and various mobile payment solutions are also increasingly widely available.

The public has become aware of the concept of the 'cashless state' through the example of Sweden, but there are also frequent reports on the Netherlands and Great Britain, showing them to be front-runners in the widespread utilisation of electronic payments. Instant cashless payment solutions are undergoing continuous development, their speed and reliability are increasing year after year and, in addition, increased attention is being directed to blockchain or 'distributed ledger' (DLT) technologies which may applied in the area of payments by both companies and central banks (see for instance Bech et al. 2017, FIS 2018). At the same time, the expansion of cash volume in various countries is also a generally observed international phenomenon, which seemingly contradicts the development of payment systems. According to MNB data, the value of forint banknotes and coins in circulation has been increasing continuously since 2012, at an average annual rate exceeding 10 per cent, surpassing HUF 6,500 billion by December 2019. The increase in cash demand was particularly strong in 2018 with an outflow of over HUF 850 billion from the central bank in a single calendar year. But this is not just true for Hungary. Examining data from foreign central banks, we can establish that practically all states in the world were faced with similar phenomena in the past decade.

What is then the truth about cash and what can we expect in the coming years? This paper first briefly presents the growth of cash in circulation in Hungary observed in recent years, introduces and organises the relevant studies published in international literature relating to cash demand, and then, in light of these data, attempts to interpret domestic processes, while detailing certain foreign examples worthy of study. Then - again relying on international literature - it focuses on the future of cash and the opportunities for cashless economies.

\section{Changes in domestic cash demand}

Based on MNB data, in terms of value, cash in circulation in Hungary has increased by 14 per cent on average each year since 2012, surpassing HUF 6,500 billion by December 2019. This is in sharp contradiction with public opinion, according to which, as a result of continuously developing electronic solutions, cash as a means of payment is now considered outdated and old-fashioned.

In the past decade, Hungary simultaneously saw both a sharp increase in cash in circulation and the swift spread of electronic payment solutions. The OCR (online cash register) database, containing the data of stores required to use online cash 
registers, ${ }^{1}$ provides an accurate picture of purchase transactions broken down by various payment methods from 2015, but in order to examine a longer time horizon, it is more expedient to rely on other estimates. One possible method as applied, for example, by Khiaonarong - Humphrey (2019) - is to compare the value of annual household consumption and the annual value of purchases made by electronic payment as shown in Figure 1. The Figure shows that while the value of electronic purchases has more than tripled since 2012, the remaining part of annual consumption - which may be considered a nearly accurate approximation of cash purchases - essentially stagnated. This indicates that the increase of cash in circulation is not the result of a change in household payment habits.

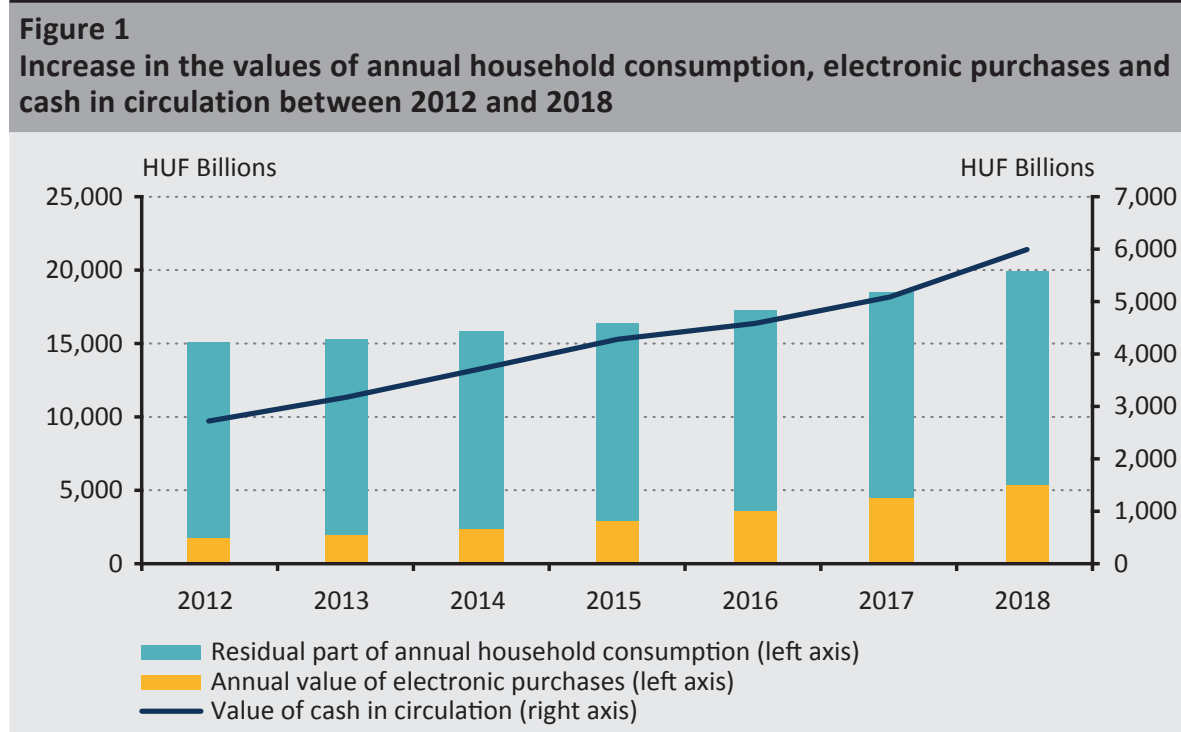

Source: $\mathrm{HCSO}, \mathrm{MNB}$

At the same time, it is important to stress that - despite the rise in the use of cashless payment solutions - cash continues to be the means of payment used most frequently and in the highest value in Hungary. According to the Payment Systems Report published by the MNB (2019a), in 2017, in terms of transaction numbers 85 per cent of purchases executed on online cash registers were made in cash, while in terms of value the figure was 68 per cent. The ratio of cash transactions registered decreased by more than 5 per cent between 2015 and 2017 , but the total number of such transactions dropped by only 1 per cent. It is a telling research result that - according to a 2018 survey based on self-declaration

${ }^{1}$ Stores required to use online cash registers by the National Tax and Customs Administration primarily represent the retail sector. 
- 46 per cent of the Hungarian population uses only cash to make day-to-day purchases, while 28 per cent use both cash and card payments and only 26 per cent prefer cashless solutions (Végső et al. 2018).

Understanding the apparent contradiction between the rising cash demand and the counter-directional change in consumer habits is facilitated by awareness of the fact that the strong growth of cash in circulation seen in recent years primarily involved the highest-denomination, 20,000 HUF banknotes. The quantity of this particular denomination in circulation almost tripled between 2012 and 2019, while the growth for 10,000 HUF notes was approximately 70 per cent, with a 25-40 per cent increase observed for smaller denominations (the distribution by value among the various denominations is shown in Figure 2). Although no methodologically sound, quantified estimates have been made in Hungary as yet, it can be reasonably assumed that the majority of high-denomination banknotes do not serve transactional purposes, and instead are used for medium- to long-term savings purposes. Consequently, the increase of this part of cash in circulation is independent of the spread of electronic payment solutions and is instead impacted by other factors (for example, the permanently low interest rate environment or the fear of economic instability, for more details see Chapters 3.2. and 4.3.).

Increased demand for high-denomination banknotes was observed to varying degrees in many other countries as well, and as such the phenomenon also drew the attention of central banks. Examining data from Great Britain, Australia and Canada, Flannigan - Parsons (2018), for example, showed significant correlation between housing prices, the value of renovations and the turnover of highdenomination banknotes, while other explanatory factors included the fear of financial instability.

\section{Figure 2 \\ Distribution of the value of cash in circulation in Hungary by denomination between 2006 and 2018}

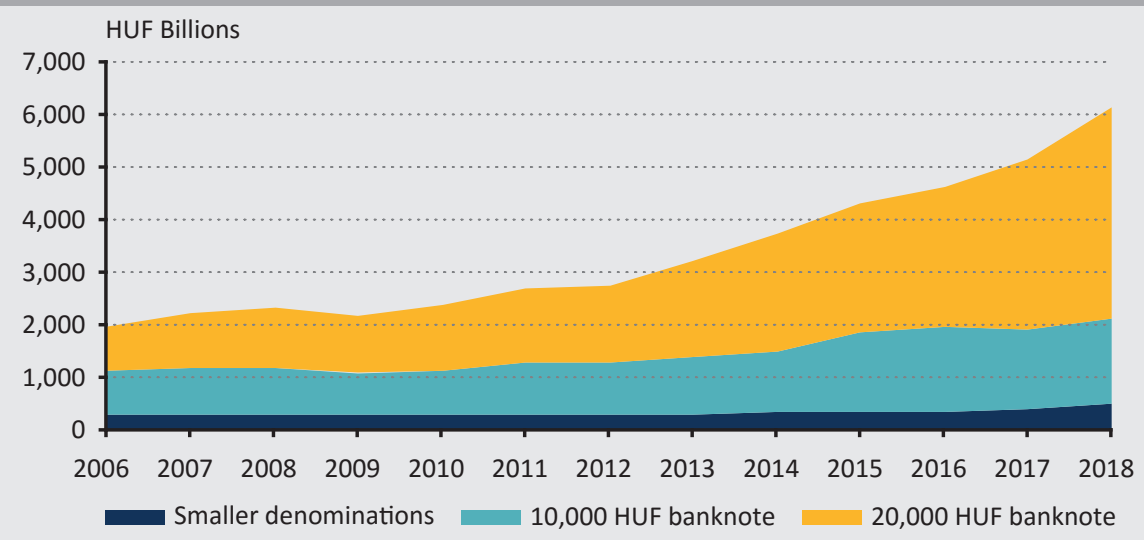

Source: $M N B$ 
The savings-related motivation of domestic demand for cash is also supported by the fact that based on HCSO data on national accounts, the assets of Hungarian households held in cash nearly doubled between 2013 and 2018, rising from HUF 2,537 billion to HUF 4,788 billion. The change in saving habits, along with other factors impacting cash demand, is discussed in detail in Chapter 4.3.

\section{What do we need cash for?}

In order to understand the situation of cash, examined in either a domestic or international comparison, it is not enough to speak merely of general cash demand. In practically all countries in the world, transactional cash demand and cash demand for savings purposes can be clearly separated, which may simultaneously be characterised by opposing movements. In addition - although slightly overlapping with the previous two categories - separate mention must be given to demand from abroad for the currency of a given country, as well as the cash usage of the shadow economy, which is linked to illegal activities (for instance, tax avoidance, black labour, smuggling) and which, given its nature, is particularly difficult to estimate.

\subsection{Transactional cash demand}

Historically, the primary purpose of the creation of cash was to facilitate the exchange of various goods and services. Banknotes and coins retain this function to this date, but starting from the second half of the 20th century, numerous other solutions surfaced in this area, from the issuing of cheques through transfers between bank accounts and card payments all the way to solutions provided by mobile phones.

The spread of cashless payments naturally reduces the ratio of cash within transactional turnover, but banknotes and coins still remain the most popular and most widely used means of payment in the world (G4S 2018). Compared to other areas of cash use, transactional cash demand and the changes therein are relatively easy to estimate, either using commercial data services such as the Hungarian online cash register database, or representative retail surveys (that typically also contain payment diaries). Such surveys and research are regularly published by the European Central Bank (Esselink - Hernández 2017) and the Fed (Greene - Stavins 2018), as well as by other central banks, such as Switzerland (Schweizerische Nationalbank 2018), Germany (Deutsche Bundesbank 2018), the Netherlands (Jonker et al. 2018), Canada (Fung et al. 2015), Japan (Fujiki - Tanaka 2018) and Australia (Doyle et al. 2017); recent analyses based on Hungarian data are also available (Végső et al. 2018 and Ilyés - Varga 2015).

One common element of the referenced studies is that - although the popularity of cash as a means of payment is considered permanent in many places, including 
Hungary - they typically report a relative decrease in transactional cash usage which, however, in the specific countries is not accompanied by a drop in overall demand for cash. According to the estimates of Fujiki - Tanaka (2018), during 2017 in Japan the value of transactional cash demand replaced by electronic payments represented merely 0.4 per cent of total currency in circulation. There is general consensus among economists with regard to the fact that demand for cash is now primarily defined by the need for savings (Assenmacher et al. 2019; Bech et al. 2018; Flannigan - Parsons 2018; Jobst - Stix 2017).

Various socio-demographic factors clearly impact the cash usage of households for transactional purposes, but the specific nature and direction of these impacts can vary greatly from nation to nation. One illustrative example concerning the results of relevant questionnaire surveys is that in Hungary, preferences for payment methods (primarily cash and bank cards) are strongly influenced by academic qualification and household income, while age in itself shows little correlation with payment habits (Végsö et al. 2018). By contrast, examining the same issue in France (Politronacci et al. 2018), qualifications and income were found to be insignificant in terms of cash usage, while age was closely linked to the choice between different methods of payment.

However, the findings of Sisak (2011) and Arango-Arango - Suárez-Ariza (2019) seem to have more general validity, according to which, based on international data, the variables expressing the level of development of countries' payment systems show strong negative correlation with transactional cash demand. It has also been widely shown that the subjective perception of the various payment methods (Khan et al. 2015) and the related costs (Arango et al. 2015; Stavins 2018) also significantly influence household payment habits, and thereby transactional cash demand. These statements are also supported by the results of questionnaire surveys in Hungary (e.g. Végső et al. 2018). The paper by Bech et al. (2018) on demand for small-denomination notes also produces interesting results, namely that the average age of the population and per-capita-GDP play a significant role (the former in a positive, the latter in a negative direction).

\subsection{Cash as a store of value}

Most of the above referenced research projects focusing on transactional cash demand also attempted to gauge cash demand for savings purposes. But given the fact that according to households one of the biggest benefits of cash is anonymity (Végsö et al. 2018), the self-declaration method is only moderately suitable to determine the actual size of this phenomenon.

Analyses performed using econometric tools provide a slightly more accurate picture. Anderson (1977), for example, developed a method taking banknote lifecycles into consideration, based on the observation that banknotes held for 
savings purposes have lower wear-and-tear than their counterparts that are involved in day-to-day cash circulation. In contrast, Sumner (1990) determines the volume of cash holdings through the seasonality of demand for banknotes, as he feels that this type of demand does not show significant fluctuation within a given month or year, while in transactional cash usage a significant temporary growth is observed at the start of months and during major holidays. According to the findings of Bartzsch et al. (2011a, 2011b), whose analysis also uses the abovementioned methods, a mere 10-15 per cent of euro banknotes issued in Germany at the beginning of the 2010s served transactional purposes. The ratio of cash held domestically as savings is estimated to be at an additional 10-30 per cent, while the remaining 60-70 per cent is taken abroad, presumably also for savings purposes. With regard to France, Politronacci et al. (2017) also determined similar ratios as far as the rate of transactional cash demand and cash demand for savings purposes are concerned, while the study by Assenmacher et al. (2019) using Swiss data showed that Swiss franc banknotes serve as store of value at a similar ratio of 55-70 per cent, with this proportion even greater for the highest denomination, the $1,000 \mathrm{CHF}$ note, ${ }^{2}$ where it can exceed 90 per cent.

According to Fujiki - Nakashima (2019), savings held in cash represent a somewhat smaller part, 40-45 per cent of the total volume of Japanese yen banknotes, while the findings of Judson (2017) show that US dollar banknote savings in foreign hands alone could represent as much as 70 per cent. Although foreign demand is somewhat lower than the estimates for the US dollar, it may still play a significant role in the turnovers of the euro (Lalouette - Esselink 2018), the Swiss franc (Assenmacher et al. 2019), the British pound and the Canadian dollar (Flannigan - Parsons 2018). It should be noted that foreign demand for certain currencies can serve more than just savings purposes. For example, in Ecuador the US dollar has been legal tender since 2000, and since 2002 - based on their own unilateral decision - Kosovo and Montenegro have both been using euro banknotes and coins.

Jobst - Stix (2017) attempts to provide an explanation for the drastic rise in cash volume in the developed world in recent years, and the increase in cash holdings in particular. As part of a data analysis covering 70 countries, the authors establish that the most significant rises in the cash-to-GDP ratio can be linked to the financial crisis of 1929-1933, World War II and the financial crisis of 2007-2009, for both the US and Europe. According to the related hypothesis of the authors, the increasing cash demand for savings purposes currently observed worldwide cannot be solely explained by the low interest rate environment or the role of the shadow economy; it also requires the uncertainty generated by the socio-

\footnotetext{
${ }^{2}$ As per the exchange rate in December 2019, the value of the 1,000 CHF note was approximately HUF 300,000 .
} 
economic crisis that can impact the way of thinking of households, as well as the corporate and financial sector for many years.

The effect of the interest-rate environment on demand (for savings purposes) for high-denomination banknotes is confirmed by the analyses of both Sisak (2011) and Bech et al. (2018), however, the latter surprisingly were unable to show significant correlation in the countries they examined between variables expressing macroeconomic uncertainty and demand for high-denomination notes.

\subsection{Cash in the shadow economy}

A frequent criticism of cash is that the liquidity and anonymity it provides is the perfect breeding ground for various illegal activities in the shadow economy. Former IMF and Fed economist and Harvard professor Kenneth Rogoff (2016) is of the same opinion. One of the key statements of his book entitled The Curse of Cash is that since cash currently plays an important role in financing corruption, smuggling and terrorism, its discontinuation would provide major assistance in eliminating these activities.

However, confirming or refuting this statement or determining the rate of cash used in the shadow economy is made extremely difficult by the fact that, on the one hand, on account of its illegality the extent of the shadow economy itself can only be estimated inaccurately, using indirect means, and on the other, within data analyses, the cash generated by illegal activities is very difficult to separate from legal transactions and legally held savings. Accordingly, the relevant international literature also contains numerous, often contradicting research results. Using data from multiple US states, Wright et al. (2017) come to the conclusion that moving social welfare and allowances to an electronic basis considerably reduced the rate of break-ins, thefts and street crime, while Immordino - Russo (2018) show significant correlation between tax avoidance (primarily meaning VAT fraud) and bank card use. Importantly, however, according to the authors the use of cards for payment purposes is linked to the reduction of tax avoidance, while cash withdrawals from ATMs show an opposite correlation. Examining the cash turnover of the euro area, Seitz et al. (2018) establishes that the estimated size of the shadow economy has no significant effect on demand for cash. Demand for the highest denominations statistically shows no significant correlation with illegal activities, and even in the case of medium denominations, only data for a few countries show correlation, but these are also weaker than expected. The regression analysis by the central bank of Germany (Deutsche Bundesbank 2019) shows significant positive correlation in certain cases between unemployment, the number of drug-related criminal offences and local cash demand, but due to the numerous uncertainty factors, the authors feel that the results are suitable to draw conclusions regarding the relationship of cash and the shadow economy only to a limited extent. 


\section{International comparison of domestic data}

Correct interpretation of domestic processes requires familiarity with regional, European and global trends. The use of nominal values - or their percentage changes in order to avoid exchange rate fluctuations - may seem logical in comparing the outflow of cash and the cash volume in circulation, but the use of the so-called cash-to-GDP ratio is considerably more widespread in general practice. This particular indicator expresses the value of banknotes and coins in circulation relative to the gross domestic product of the given country. Its introduction is based on the underlying logic that the cash demand of a country's economy can change even with constant household and corporate payment and savings habits, if the economy's capacity increases or decreases. Another benefit in terms of comparability is that it is free of the distorting effects of exchange rate fluctuations.

Accordingly, the remaining part of the chapter only touches on conclusions drawn from nominal volume data and places greater emphasis on cash-to-GDP ratios as well as factors potentially impacting demand for cash. In addition, some international examples that provide lessons in respect of the current and future situation of cash are also presented in more detail.

\subsection{Nominal cash volume}

Examining the nominal data of the central banks of the euro area and the Central Eastern European region, we can establish that the strong increase in cash demand in recent years was not only typical of Hungary (Figure 3). Taking 2008, representing the start of the economic crisis, as a basis, we can observe that the volume of cash in circulation grew at a rate similar to Hungary in Romania and until 2016 - in Poland as well. A constant, although in nominal terms considerably lower increase was seen in the Czech Republic and the euro area. It must, however, be emphasised that the examination of the nominal change in cash volume has very slight relevance if the economic indicators (e.g. inflation, income changes, interest rate level) typical of the given country are not taken into consideration. 


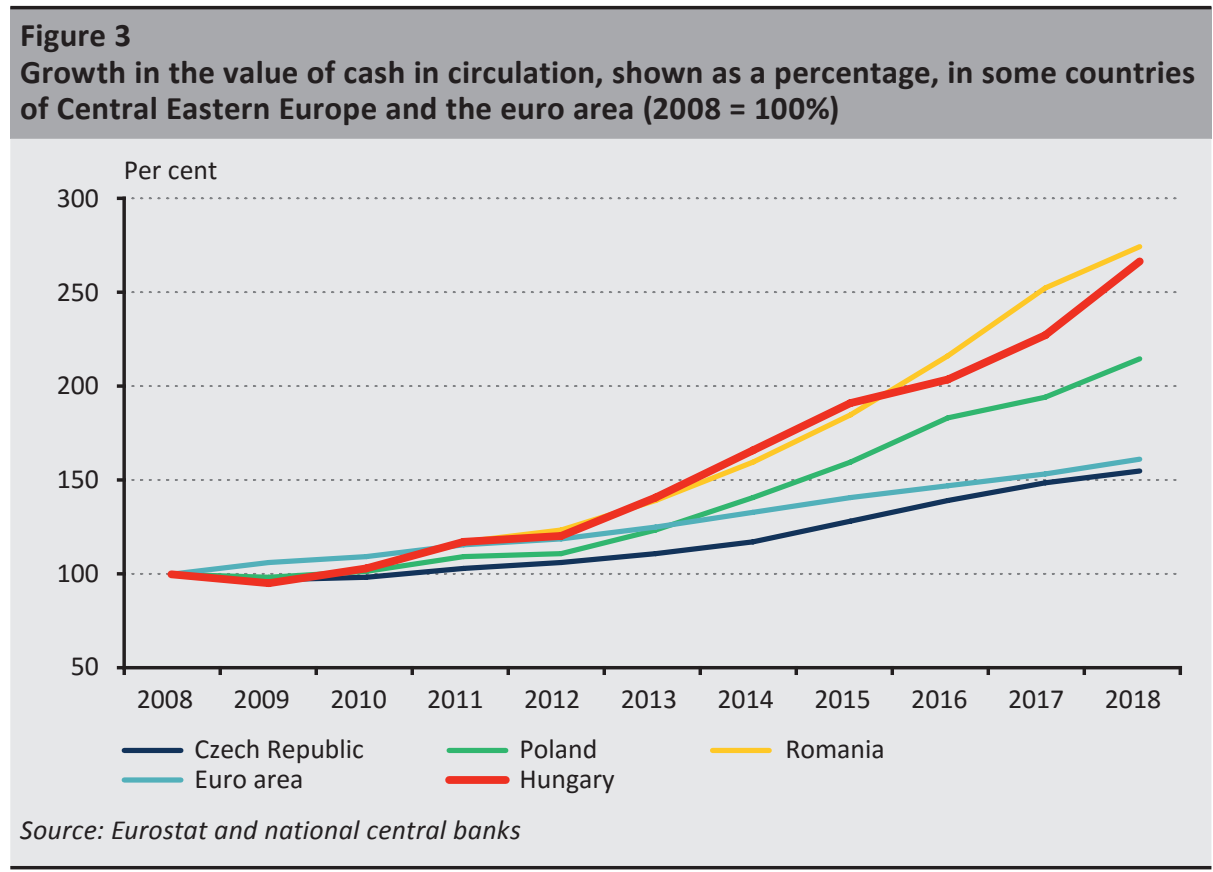

As is the case in Hungary, it is not typical of the region that the highest-denomination banknote represents the majority of the cash volume in circulation. In recent years, a shift of the denomination structure towards higher denomination banknotes was seen essentially everywhere, but the increase in demand typically concerned the second or perhaps third highest denominations (Figure 4). The situation is slightly nuanced by the fact that, adjusted for purchasing power parity, ${ }^{3}$ the highest banknote denominations of the euro area ${ }^{4}$ and the examined countries are all (1.5-2.5 times) greater than the 20,000 HUF banknote, and that these high-value banknotes are typically not or are only rarely offered by ATMs. This allows us to reasonably assume that in these cases, savings purposes could also be significant for the second or perhaps the third-highest denominations as well. These data, therefore, do not allow us to clearly state that transactional demand in the neighbouring countries would have had proportionally greater effect on the growth of cash in circulation than in Hungary.

\footnotetext{
${ }^{3}$ The source of PPP conversion values is the World Economic Outlook (October 2019) database compiled by the IMF.

${ }^{4}$ For the euro area, we considered the 200 EUR banknote to be the highest denomination, as the EUR 500 note - although still considered legal tender - has not been issued since April 2019, and its volume in circulation recently has essentially stagnated.
} 


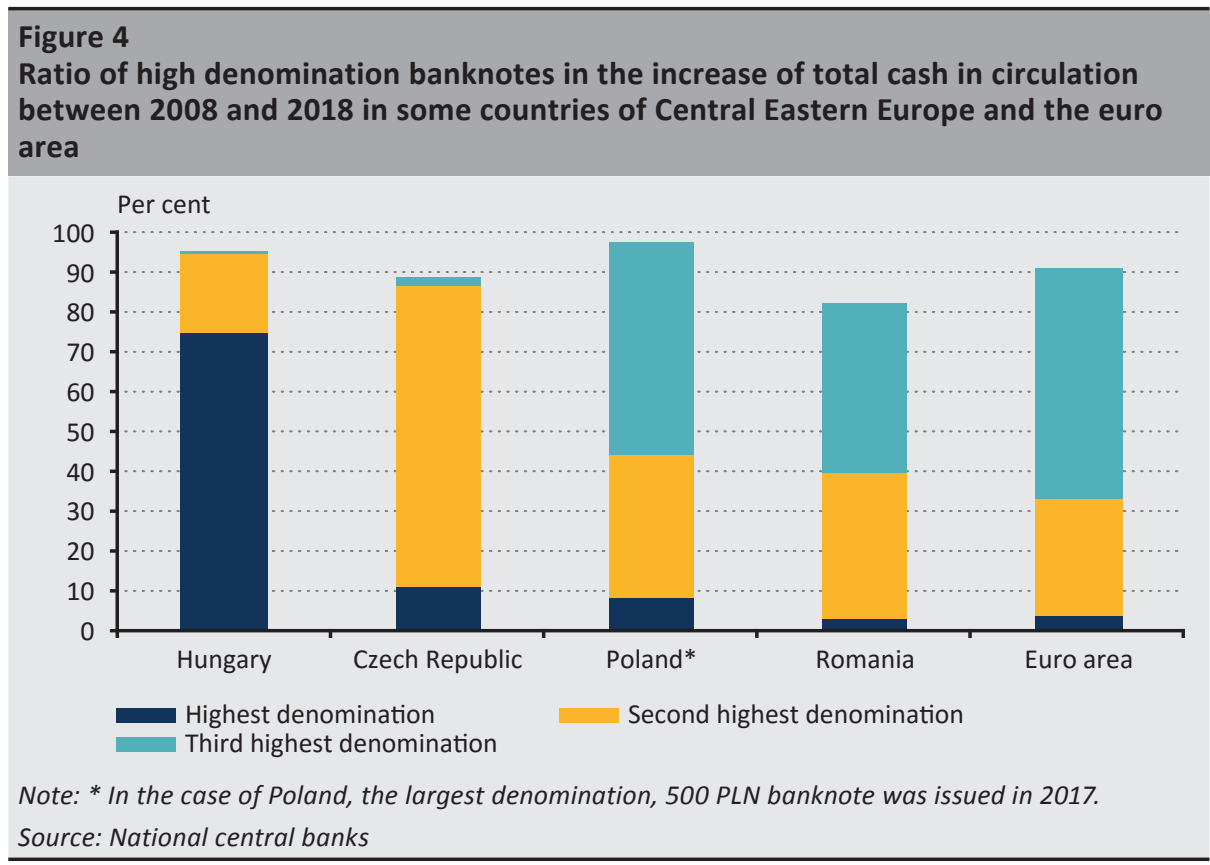

An illustrative piece of data on the global state of cash is that, according to data from central banks, there are only two countries in the developed world that have seen a lasting nominal decline in the cash volume in circulation in recent years: Norway and Sweden. In the case of the former, the decline has been recorded only since 2015, while for the latter, the reduction in banknotes and coins in circulation has been ongoing for 10 years, but surprisingly the trend turned around in 2018. The value of cash in circulation in Sweden increased by 7.2 per cent during the year. The possible reasons for the earlier decrease are detailed in Sub-chapter 4.4.1.

\subsection{Cash-to-GDP ratio}

In respect of domestic data pertaining to this indicator, we can state that between 2012 and 2018 - similarly to nominal value - the cash-to-GDP ratio increased substantially in Hungary, rising by more than 150 per cent over the course of six years (Figure 5). 


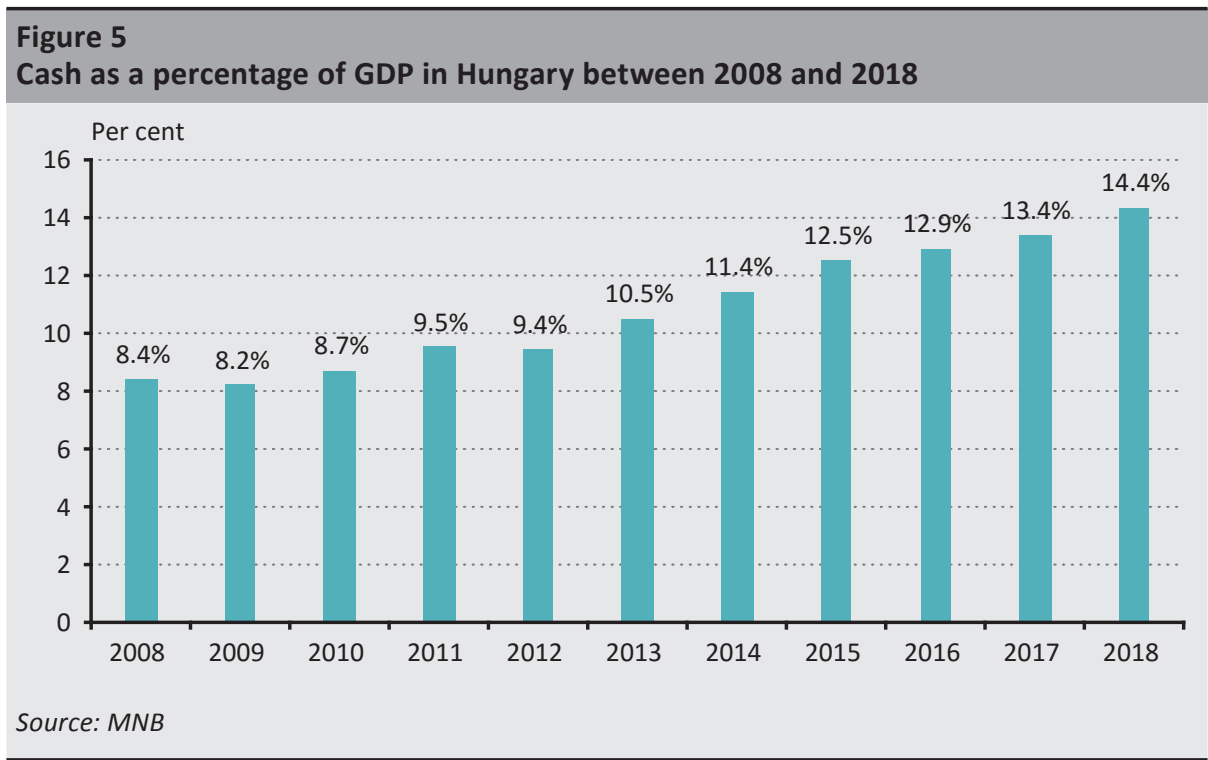

Comparing the Hungarian values for 2018 with the euro area ${ }^{5}$ and the EU Member States which have their own currency (as well as Switzerland), we come to the same conclusions as in examining the nominal increase. The Hungarian cash-toGDP ratio can be considered high in a European comparison, but the difference is not outstanding, neither compared to the neighbouring countries nor to the euro area (Figure 6). According to the World Cash Report issued by British group G4S (2018), one of the world's largest cash logistics providers, aggregate global cash in circulation relative to GDP has been continuously increasing since 2011, with its current estimated value at close to 10 per cent. The aggregate value for Europe is only slightly lower, at around 9 per cent, and is also characterised by continuous growth.

It is worth noting that the value of the indicator for the euro area is 2 percentage points higher than the Romanian data, and that - extending the comparison to other continents as well - it considerably exceeds the value for Turkey and is only 0.6 per cent behind the figure for India. This illustrates well that the cash-to-GDP ratio is not always suitable for comparing the level of development of the payment infrastructures of various countries, the rate of cash usage or the attitude of the population and companies towards cash. The fundamental reason for this is the significant difference between the central bank base rate in developed and developing countries both today and historically. Differences in foreign demand for the currency of a given country may also be substantial in some cases. Albeit

\footnotetext{
${ }^{5}$ Based on the location of issuing cash into circulation, the cash-to-GDP ratio can also be estimated separately for the various Member States of the euro area, but these estimates are highly inaccurate on account of the extensive flow of cash between these countries, and can only be used to draw reliable conclusions to a limited extent; consequently, they are not taken into consideration in this analysis.
} 
to a considerably lesser extent than the aspects above, cultural factors influencing the consumption and savings habits of households may also play a role.

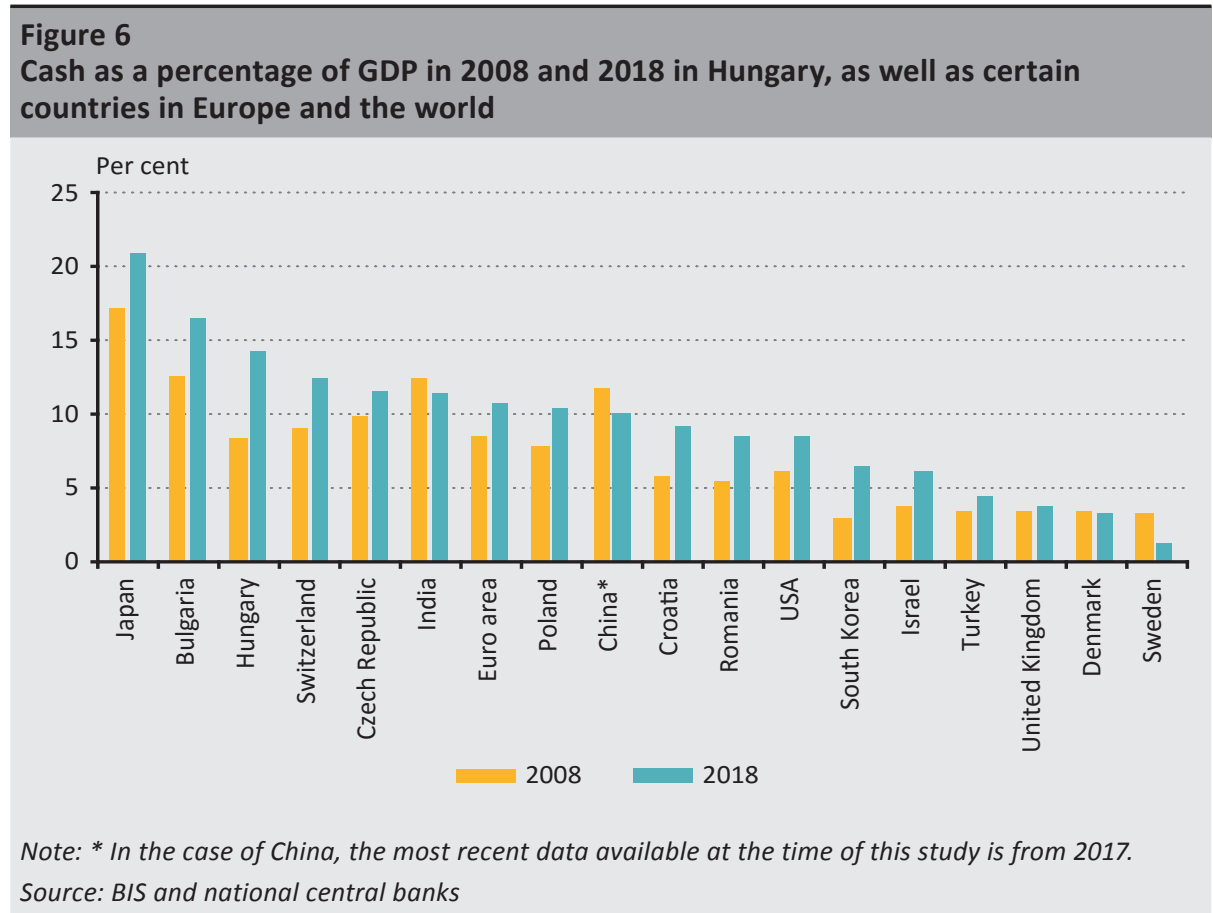

Khiaonarong and Humphrey (2019) provide further criticism on using the cashto-GDP ratio. They are of the opinion that the ratio would only have the meaning attributed to it if it did not take the whole of GDP, but only its components arising from consumption into consideration, as this is the area were cash would actually be used. However, applying their proposal is made very difficult because the necessary data in many of the countries examined in this paper are not available. In addition, the authors only take into consideration to a limited extent that the majority of the cash volume presumably serves savings and not consumption purposes.

\subsection{Factors explaining the domestic increase of cash in circulation}

As previously presented, the increase of cash in circulation in Hungary is almost exclusively the result of rising demand for higher denominations, and this phenomenon is also observed - to varying degrees - in some of the neighbouring countries.

Given that higher denominations primarily serve savings purposes, we can conclude that changes in household savings habits may have a significant impact on cash demand. The opportunity costs of cash holding depend strongly on the central bank base rate, meaning that the development of the base rate level may 
explain the different changes in cash volumes in the given countries as shown in Figure 6. This is particularly striking in the case of Japan, where the base rate - that has been near zero since the mid-1990s - is accompanied by a cash-to-GDP ratio that is outstanding even by global standards, but it is also true for Turkey or India that interest rates which are high in an international comparison result in lower cash-to-GDP ratios than in countries of the developed world. Although the growth in Hungary observed since 2012 is significantly impacted by the low interest rate level (see for example Lybek - Dybczak 2019), this in itself does not explain the differences compared to the neighbouring countries, as this phenomenon can be seen in practically all countries in Europe.

Further interesting conclusions may be drawn for Hungary from the joint examination of cash in circulation, the central bank base rate and the euro exchange rate (Figure 7). We can observe that the EUR/HUF exchange rate and the volume of cash in circulation typically changed in an identical direction between 2008 and 2012, meaning that the weakening of the HUF against the EUR was accompanied by an increase in cash demand. As far as key international currencies are concerned, similar phenomena are seen (see for example Miller 2017), but the underlying reason for these is primarily demand from abroad, which in the case of the forint is presumably negligible. In the period reviewed, the role of the exchange rate - as the indicator expressing the stability and performance of the financial-economic system - in Hungary may be more dominant, as the sudden dips of the HUF were typically linked to crisis situations, which may have also been accompanied by a loss of confidence from households in the banking system.

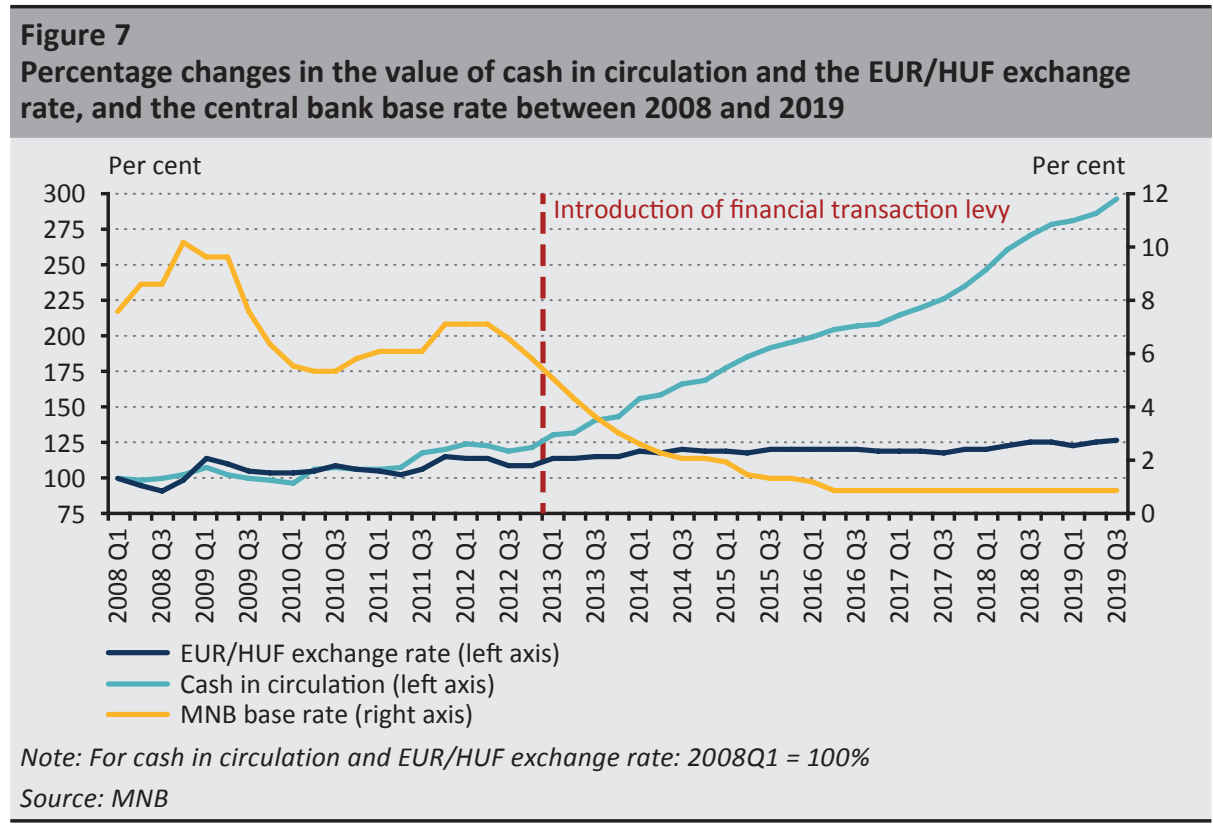


Figure 7 shows the breaking point in the data series in 2012-2013, i.e. the acceleration of the increase in cash volume, which more or less coincides with the start of the rate-cutting period. In the lower interest rate environment, cash is no longer simply a 'safe haven', but also a realistic form of savings for the long term. At the same time, the financial transaction levy was also introduced, which also may have had a significant impact on cash demand, primarily through the transactional use of higher denominations (for more details, see the end of this Sub-chapter).

The European Central Bank coordinated a series of surveys in two phases in recent years on household savings habits as well as the factors impacting these habits, and both the MNB (MNB 2017 and MNB 2019b) and the National Bank of Poland (NBP 2015 and NBP 2017) were involved in these surveys. The common conclusion drawn from the surveys is that in the years reviewed, in line with the increase in incomes, the value of households' financial assets also rose substantially in both countries, but for questions pertaining to cash holdings, the willingness to respond was extremely low, making it more expedient to rely on data from national accounts.

HCSO data between 2008 and 2018 clearly show that starting from 2012, the value of cash holdings increased continuously and at a strong rate, while the expansion of deposit volumes is considerably more moderate (Figure 8). Impressively, the ratio of cash among household assets grew from 21 per cent to 33 per cent between 2012 and 2018. According to Jobst - Stix (2017), the possible reasons for this could include the financial and socio-economic uncertainty caused by the economic crisis of 2007-2009 and the crisis in the euro area between 2010-2013, which may have pushed households towards holding cash, which they perceived

\section{Figure 8 \\ Change in the financial assets and cash holdings of Hungarian households between 2008 and 2018}

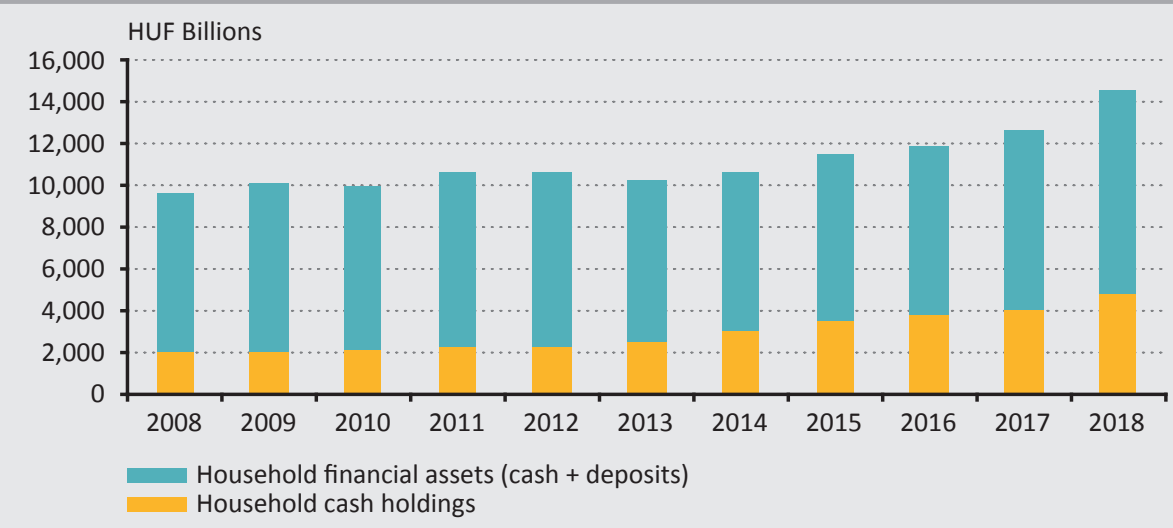

Source: HCSO 
as more reliable. In Hungary, this effect and - as a result - the loss of confidence in banks may have been spurred by the liquidation of numerous brokerage firms and credit institutions in 2014 and 2015.

The objectives of the Hungarian Government Security Plus product issued from June 2019, offering above-market returns with low risk, included reducing the cash hoarding of households, but MNB data show that this was not realised in the first few months. Cash in circulation increased - albeit at a decelerating rate between June and September 2019 versus the same period of the preceding year (rising by HUF 135 billion and HUF 278 billion, respectively), and this essentially coincides with the trends observed in the first five months of 2019 , which also reflect deceleration (growth of HUF 62 billion and HUF 350 billion, respectively).

The rise in the ratio of households' financial assets held in cash stands out, both in comparison to neighbouring countries and the euro area, although a slight shift towards cash holdings can be observed for Romania and Poland as well starting from 2012 (Figure 9). Lybek - Dybczak (2019) examined the effects of banking sector crises and the resulting economic uncertainty on cash volume, specifically looking at Hungary, using data from between 2000 and 2018 and applying regression analysis, but the authors were unable to show any significant correlation. Although the effect of the above phenomena on households' way of thinking is difficult to quantify, diminishing the reliability of results, is still allows us to conclude that the crises of the past decade in themselves do not provide sufficient explanation for the strong growth in Hungarian cash demand.

\section{Figure 9 \\ Ratio of cash in households' financial assets between 2008 and 2018 in some Central Eastern European countries and the euro area}

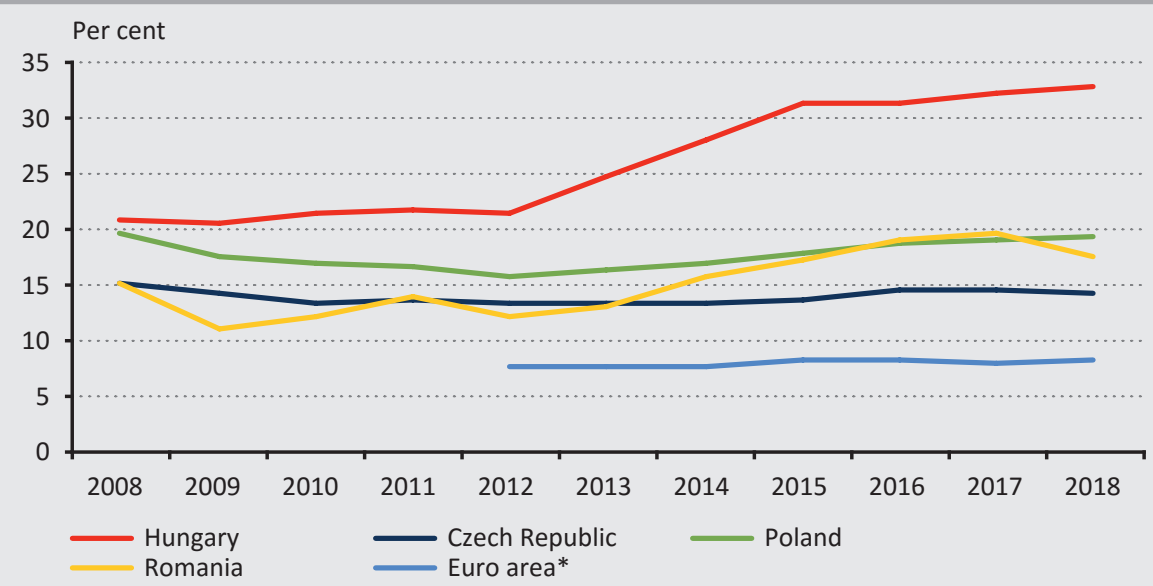

Note: * In the case of the euro area, the data series is only available from 2012.

Source: Calculation based on HCSO and Eurostat data 
We should also take into consideration the possibility that, in some cases, high denominations may also serve transactional purposes, meaning that in addition to long-term savings, holding cash could also be aimed at settling future transactions. According to the previously mentioned results of Flannigan - Parsons (2018), such transactions could include payments related to home purchases and renovations, although the real estate price indexes of Hungary and the neighbouring countries (using MNB and Eurostat data) show no significant correlation with demand for cash; this is well illustrated by the fact that between 2008 and 2018, Romania saw a strong increase in cash volume while the price index dropped.

The financial transaction levy-which in this particular form is only typical of Hungary - may have an impact pointing to the transactional use of high denominations, as it concerns retail and corporate banking transactions (in the case of the former only over HUF 20,000) as well as cash withdrawals (with the exception of the freeof-charge withdrawal twice a month, in a value of HUF 150,000 at the most, as set out by legal regulations). According to the survey-based results of Belházyné et al. (2018), large-amount cash transactions became more frequent between 2013 and 2017 in the Hungarian SME sector, while according to Végső et al. (2018), in a European comparison Hungarian households typically withdraw larger amounts of cash to optimise banking costs, which necessarily also involves withdrawing higher denomination banknotes. According to the regression analysis by Lybek - Dybczak (2019), the introduction of the financial transaction levy explains the stronger growth in cash demand observed after 2013 (Figure 7). However, according to the authors, the new national instant payment system set to launch in March 2020 and impacting all banks, could - with suitable pricing - play a key role in mitigating the rate of cash transactions.

\subsection{Lessons from international examples}

The following section presents the cash landscape characteristics of a few countries not discussed in the previous sub-chapter, but shown in Figure 6, primarily focusing on states that have unique properties that can be well outlined.

\subsubsection{Sweden}

Among the countries examined, the situation of Sweden is perhaps the most unique, as - except for Norway where this trend started only in 2015 - this is the only country where a lasting, continuous drop in nominal cash volume was seen in the past decade, while the cash-to-GDP ratio also halved between 2012 and 2018. According to Arvidsson (2019), this phenomenon owed much to the decision of the central bank of Sweden providing a very short period of only a few months to exchange old, high-denomination banknotes withdrawn from circulation when it issued its new banknote series in the 2010s. Together with a wave of bank robberies committed in the country shortly before which received significant 
publicity, this greatly undermined confidence in cash as a simple and secure means of savings. At the same time, the Swedish government implemented measures to combat the shadow economy and to reduce tax avoidance, which specifically targeted the construction industry and various household services (e.g. gardening, child supervision), thereby primarily reducing transactional cash demand but, to a smaller extent, cash demand for savings purposes as well. In addition, Arvidsson (2019) and Engert et al. (2019) emphasise the role of the spread of cashless bank branches which, on the one hand, motivated retailers to favour electronic payments in both buyer and supplier relationships and, on the other, by limiting the use of cash, presumably continued to lower the popularity of holding savings in cash.

Overall, we can establish that Sweden managed to accomplish a lasting, significant reduction of cash in circulation primarily by reducing cash held for savings purposes. The reduction of transactional cash usage was of a similar rate in other developed countries, including Norway, Denmark (Smestad 2017), Canada (Engert et al. 2019), the Netherlands (Jonker et al. 2018) or the United Kingdom (Greenham - Travers-Smith 2019), but this in itself was insufficient to reduce nominal volume.

Moreover, it should also be mentioned that following the 2002 issue of euro banknotes, Finland (neighbours to Sweden) saw a stronger-than-expected surge in cash demand, which was not supported by local household transaction data (Kangas 2019). As this period more or less coincides with the 2006-2007 start of the drop observed in Sweden, it is also possible that the Swedish population keeps some of its cash holdings in euro banknotes from Finland instead of Swedish krona.

\subsubsection{Israel}

From a Hungarian perspective, the example of Israel has particular relevance, as it is one of the few countries where - similarly to Hungary - the two highestdenomination banknotes ${ }^{6}$ represent the majority of cash in circulation (54 per cent and 27 per cent, respectively, according to end-2018 data from the central bank). According to the assumptions of the Israeli government, high-denomination banknotes facilitate tax avoidance as well as the operation of the shadow economy, which is why a bill was submitted in 2015 aimed at prohibiting high-volume cash transactions as well as exaggerated cash holdings mainly rooted in cultural reasons, which applied to both business payments as well as payments between private individuals (Fein 2018). After numerous amendments and lengthy social debate, the bill was passed by the Israeli parliament in February 2018, with the law entering into force on 1 January 2019 (Fein 2019).

\footnotetext{
${ }^{6}$ As per the exchange rate in December 2019, the value of the 200 ILS note was approximately HUF $17,000$.
} 
The law capped cash transactions at ILS 11,000 (after adjustment for purchasing power parity approximately HUF 380,000) in business transactions, and at ILS 50,000 (after adjustment with purchasing power parity approximately HUF 1.74 million) for transactions between private individuals. According to the data of the Bank of Israel, the value of cash in circulation in the country in 2019 stagnated afterwards, but this is not considerably different from the trend of previous years showing decelerating growth. This is why it may be useful down the line to examine whether the composition of Israeli cash volume changes in the long term as a result of the act, whether the expected growth in tax revenues and the suppression of the shadow economy is realised, and whether the measure causes problems for the part of the population that has no access to bank accounts.

\subsubsection{India}

In 2016, the government of India turned to an even more drastic method, so-called demonetisation, to suppress large-scale cash transactions and cash holdings linked to the shadow economy. With an unexpected announcement by Prime Minister Narendra Modi on 8 November, the highest-domination 500 INR and 1,000 INR banknotes were withdrawn from circulation with effect at midnight the same day, with the government providing only until the end of the year to exchange them. According to the report of the Reserve Bank of India (2017), more than 99 per cent of withdrawn banknotes were exchanged by the deadline set, but the cash-to-GDP ratio only dropped temporarily.

Accordingly, the measure accomplished its initial goal only to a limited extent, but it did lead to a serious crisis nationwide, which in turn also impacted agricultural production and employment. The temporary cash shortage arising during demonetisation, in contrast to the government's intentions, reinforced the role of the informal economy, and overall had a highly negative impact on poorer classes living in rural areas that had no large amount savings or access to bank accounts (Guérin et al. 2017). In addition, Chodorow-Reich et al. (2018) used mathematical models to confirm that regions where cash shortage arising as a result of demonetisation was greater saw a more substantial decline in both the performance of the economy and lending.

\subsubsection{China}

Chinese households have a traditionally high savings rate - which has actually started dropping in recent years - with a particularly high share of cash holdings (Zhang et al. 2018). As a result of the financial liberalisation seen in the 2010s and the higher yields offered by the increasingly robust shadow banking system (Elliott et al. 2015), the popularity of cash holdings seems to be dropping today, and one consequence of this is a decline in the cash-to-GDP ratio. Another contributing 
factor may be the relatively low value of the highest banknote denomination. ${ }^{7}$ It must also be noted that the Chinese payment landscape is strongly characterised by the swift spread of innovative cashless solutions. By this, we primarily refer to mobile phone payments (G4S 2018), but this is also where payment methods based on facial recognition (i.e. not requiring any other tools for the transaction) first appeared in great numbers.

\subsubsection{South Korea and Japan}

These two countries primarily merit mention because in the South Asian region these were the only two countries where a strong increase in the cash-to-GDP ratio was observed in recent years. In Japan, this growth started from an already very high base, the main reason for which according to Fujiki-Nakashima (2019) was cash demand for savings purposes, which accounts for 40-45 per cent of total volume. According to the authors, the expansion of cash holdings in recent years and even today exceeds the reduction arising from the spread of electronic payment solutions. The reasons for the high volume of cash holdings include the base rate that has been near zero since the mid-1990s, the ageing of society and, on a related note, attempts to avoid the exceptionally high inheritance tax (Shirai - Sugandi 2019).

In the case of South Korea, the cash-to-GDP ratio was considered to be low back at the beginning of the 2010s, but in the past decade the volume of cash in circulation increased so dynamically that its rate relative to GDP growth significantly exceeded even the values typical in Hungary (Figure 6). To a great extent, this was potentially the result of savings held in cash, which is also confirmed by the decision of the Bank of Korea to issue, prior to this increase, a new banknote in 2009 with a value higher than any of the denominations in circulation until that point. ${ }^{8}$

It should also be mentioned that at the same time, based on data by the central bank, transactional cash usage showed a continuous, swift decline, with today more than 80 per cent of payments made electronically. Furthermore, in 2017 (on a trial basis), the government launched the 'coinless society' programme, as part of which consumers can choose to load the change they receive from small purchases directly to pre-paid cards or their bank account. ${ }^{9}$

\footnotetext{
${ }^{7}$ As per the exchange rate in December 2019, the value of the CNY 100 note was approximately HUF 4,200.

${ }^{8}$ As per the exchange rate in December 2019, the value of the KRW 50,000 note was approximately HUF 12,600.

${ }^{9}$ Currency News (2017): South Korea Plans to go 'Coinless'. Currency News, 2017, 15 January, p. 3.
} 


\section{What will the future bring?}

Given that the cash demand of both the whole world economy and the various states is the result of highly complex processes, related forecasts often prove highly inaccurate. This chapter briefly introduces the potential methodologies of forecasting as well as their limitations, and then presents the possible future of a cashless society along with the social risks this entails, also touching on the issue of central bank digital currency.

\subsection{Opportunities of forecasting cash demand}

Cash circulation and demand for cash have undergone numerous structural changes in the past decade, which also makes forecasting difficult because as a result, past data only have limited explanatory power regarding the future. The associates of central banks and analysts project the continued reduction of cash usage in the developed world (for example Lalouette - Esselink 2018 in respect of the euro area, or Perkins 2019 for the US), but it has become clear that this phenomenon does not necessarily result in a drop in cash in circulation.

Miller (2017) uses the methodological framework developed by the Bank of England to present the importance of breaking the demand for cash down into components, ${ }^{10}$ and also that to achieve appropriate robustness, in addition to econometric modelling - which for instance takes household consumption, the interest rate environment and exchange rates into account as well - it is also necessary to consider qualitative factors, such as potential changes in the regulatory environment or the various directions of technological progress. In respect of cash, he also highlights the importance of forecasts having the primary objective not of determining accurate values in the future, but rather defining the range of possible outcomes, along with the accompanying probabilities.

\subsection{Vision and risks of a cashless society}

While the complete disappearance of cash may seem very distant when one examines the aggregate Hungarian or European Union data, officials at the Bank of Sweden are already trying to prepare the country's population for the possibility of a cashless society (Skingsley 2018). However, going cashless does not represent positive changes for all. According to an analysis by Greenham - Travers-Smith (2019) - which formulated recommendations for Great Britain, which is at the forefront of reducing transactional cash usage -12 per cent of the British population, by their own admission, would be unable to carry out day-to-day transactions without cash. This group primarily includes the elderly and low-income people, meaning that the abolishment of cash would have the greatest impact on societal

${ }^{10}$ Transactional cash, cash for savings purposes, foreign demand, and cash usage by the shadow economy, for more details see Chapter 4. 
classes that are already vulnerable. The end of potential anonymity may also have a negative impact on many, and the household surveys conducted in the countries concerned (for Denmark, for example, see Smestad 2017) clearly show that many people also want cash to remain accessible for purely subjective reasons.

Beyond social risks, moving payments fully to electronic platforms also entails other, primarily technology-related risks. According to Almedia et al. (2018), in a cashless society the potential errors or breakdowns of communication and electricity networks or the servers operating payment systems - that may be caused by natural disasters or even external attacks - would represent a risk considerably greater than those seen currently. Based on the Fed's data (Bau O'Brien 2019), recent natural disasters in the United States (Hurricane Harvey, for example, that swept through Texas and Louisiana in 2017) generated extremely high cash demand locally in the regions affected, even in the weeks preceding the actual disaster. This phenomenon confirms that the role of cash as a security reserve continues to be extremely important for households.

As a result, public discourse and communication by central banks is increasingly striving to replace the concept of 'cashless' and trying to emphasise the use of 'less cash' (John 2019). Although the continuous drop in transactional cash usage over the long term does point to a complete disappearance of cash as a means of payment, on the one hand, based on current experiences this does not necessarily incur the elimination of cash as a form of savings and, on the other, the social concerns regarding cashlessness may also justify maintaining the cash infrastructure for additional decades.

A key element of visions aimed at completely getting rid of banknotes and coins is the option of central bank digital currency. This solution ideally allows for the elimination of manufacturing and distribution costs linked to cash by ensuring - with appropriate state and central bank supervision - that no part of the population is under threat of being excluded from the financial system, as this would allow for the elimination of the monopoly of commercial banks and card companies in the field of electronic payments. Although we see numerous pilot and research projects examining the possibilities of implementation (Canada, China, Norway, Uruguay as per Mancini-Griffoli et al. 2018), there are currently no practical examples of central bank digital currency today, with perhaps the plans of the Bank of Sweden in the most advanced phase (Söderberg 2018). The BIS (Barontini-Holden 2019) recently concluded an international survey on this topic, while the IMF (Khiaonarong - Humphrey 2019) published a comprehensive study on the same. 


\section{Summary}

If we ask the question of whether we use too much cash, the best answer would be that although we are not using too much to make payments, we can still state that compared to the examples seen in neighbouring countries, the volume of cash in circulation today in Hungary is too high, but it primarily serves savings purposes. There is still room to grow in increasing the share of electronic payment solutions in Hungary, but we can establish that the Hungarian population is using less and less cash in line with international trends. In contrast, the volume of cash in circulation in both Hungary and the majority of developed countries is continuously rising, typically at a rate even greater than GDP growth. The key drivers of the change in Hungary - not in unprecedented fashion - are higherdenomination banknotes which, beyond making payments, households also use as an instrument of savings. This may be explained by, among other things, the permanent low-interest rate environment, the uncertainty generated by the economic crises of the past decade as well as the resulting distrust in the banking system. The role of the financial transaction levy is not negligible either, which is assumed to have an impact on the rate of higher-value cash transactions.

At first glance, the continuously increasing cash demand in Hungary may seem extreme, however - even at an international level - there are very few examples of a lasting reduction of cash in circulation, and in all such cases accomplishing this required the concurrent existence of multiple factors aimed at preventing both the use and holding of cash. In the case of Hungary, an achievable goal seems to be to reduce the average growth rate of cash in circulation to the levels seen in the euro area or the Czech Republic in the short term. The rollout of the instant payment system in 2020 could represent a major step forward down the line in accomplishing this, but reducing the fees charged for banking services or the continued promotion of attractive and accessible savings instruments could also induce favourable changes (such as the Hungarian Government Security Plus issued in 2019). However, one important lesson to draw from recent international trends and research based on these trends - a lesson that could also impact domestic cash demand in the future - is that in the wake of a global economic recession or crisis, the cash demand of households may increase significantly, even over the long run. 


\section{References}

Almedia, P. - Fazendeiro, P. - Inácio, P.R.M. (2018): Societal risks of the end of physical cash. Futures, 104(December): 47-60. https://doi.org/10.1016/j.futures.2018.07.004

Anderson, P.S. (1977): Currency in use and in hoards. New England Economic Review, March/ April, pp. 21-30.

Arango, C.A. - Huyhn, K.P. - Sabetti, L. (2015): Consumer payment choice: Merchant card acceptance versus pricing incentives. Journal of Banking \& Finance, 55(June): 130-141. https://doi.org/10.1016/j.jbankfin.2015.02.005

Arango-Arango, C.A. - Suárez-Ariza, N.F. (2019): Digital Payments Adoption and the Demand for Cash: New International Evidence. Borradores de Economía, No. 1074. https://doi. org/10.32468/be.1074

Arvidsson, N. (2019): The Story of Cash and the Route Toward a Cashless Society: The Case of Sweden. In: Arvidsson, N. (ed.): Building a Cashless Society, Springer, Cham, pp. 27-40. https://doi.org/10.1007/978-3-030-10689-8_4

Assenmacher, K. - Seitz, F. - Tenhofer, J. (2019): The demand for Swiss banknotes: some new evidence. SNB Working Papers 2/2019, February. https://doi.org/10.1186/s41937019-0041-7

Barontini, C. - Holden, H. (2019): Proceeding with caution - a survey on central bank digital currency. BIS Papers No 101, January.

Bartzsch, N. - Rösl, G. - Seitz, F. (2011a): Foreign demand for euro banknotes issued in Germany: estimation using direct approaches. Deutsche Bundesbank Discussion Paper Series 1: Economic Studies No. 20.

Bartzsch, N. - Rösl, G. - Seitz, F. (2011b): Foreign demand for euro banknotes issued in Germany: estimation using indirect approaches. Deutsche Bundesbank Discussion Paper Series 1: Economic Studies No. 21.

Bau, A. - O'Brien, S. (2019): Rethinking Volume Forecasting: Observing cash's evolution in the economy, and the subsequent impact on the cash handling industry. Lecture: Future of Cash Conference, Athens, February 19-21.

Bech, M. - Shimizu, Y. - Wong, P. (2017): The quest for speed in payments. BIS Quarterly Review, March, pp. 57-68.

Bech, M. - Faruqui, U. - Ougaard, F. - Picillo, C. (2018): Payments are a-changin' but cash still rules. BIS Quarterly Review, March, pp. 67-80. 
Belházyné Illés, Á. - Bódi-Schubert, A. - Végső, T. (2018): An Analysis of the Payment Habits of Hungarian Micro, Small and Medium-sized Enterprises - In Focus: Cash Usage. Financial and Economic Review, 17(4): 53-94. http://doi.org/10.25201/FER.17.4.5394

Chodorow-Reich, G. - Gopinath, G. - Mishra, P. - Narayanan, A. (2018): Cash and the Economy: Evidence from India's Demonetization. NBER Working Paper No. 25370, December. https://doi.org/10.3386/w25370

Doyle, M.-A. - Fisher, C. - Tellez, E. - Yadav, A. (2017): How Australians Pay: Evidence from the 2016 Consumer Payments Survey. RBA Research Discussion Papers, April. https://www. rba.gov.au/publications/rdp/2017/pdf/rdp2017-04.pdf. Downloaded: 13 September 2019.

Deutsche Bundesbank (2018): Payment behaviour in Germany in 2017. https://www. bundesbank.de/resource/blob/737278/\%20458ccd8a8367fe8b36bbfb501b5404c9/mL/ payment-behaviour-in-germany-in-2017-data.pdf. Downloaded: 13 September 2019.

Deutsche Bundesbank (2019): Cash demand in the shadow economy. Monthly Report March 2019, pp. 43-58. https://www.bundesbank.de/resource/ blob/793190/466691bce4f27f76407b35f8429441ae/mL/2019-03-bargeld-data.pdf. Downloaded: 13 September 2019.

Elliott, D. - Kroeber, A. - Qiao, Y. (2015): Shadow banking in China: A primer. Brookings Economic Studies, March.

Engert, W. - Fung, B.S.C. - Segendorf, B. (2019): A Tale of Two Countries: Cash Demand in Canada and Sweden. Bank of Canada Staff Discussion Paper 2019-7. https://www. bankofcanada.ca/wp-content/uploads/2019/08/sdp2019-7.pdf. Downloaded: 13 September 2019.

Esselink, H. - Hernández, L. (2017): The use of cash by households in the euro area. ECB Occasional Paper Series No. 201, November.

Fein, M. (2018): Limitations on the Use of Cash in Israel: A New Law. CashEssentials. https:// cashessentials.org/app/uploads/2018/07/cashlimitationsinisrael_may2018_update_ mordechai_fein.pdf. Downloaded: 13 September 2019.

Fein, M. (2019): New Cash Law sparks panic in Israel. CashEssentials. https://cashessentials. org/new-cash-law-sparks-panic-in-israel/. Downloaded: 13 September 2019.

FIS (2018): Flavors of Fast report. http://empower1.fisglobal.com/rs/650-KGE-239/images/ FLAVOR-OF-FAST-Report-2018.pdf. Downloaded: 13 September 2019.

Flannigan, G. - Parsons, S. (2018): High denomination banknotes in circulation: A crosscountry analysis. RBA Bulletin, March, pp. 1-19. 
Fujiki, H. - Nakashima, K. (2019): Cash Usage Trends in Japan: Evidence Using Aggregate and Household Survey Data. TCER Working Paper E-131, March. https://doi.org/10.2139/ ssrn.3351429

Fujiki, H. - Tanaka, M. (2018): How do we choose to pay using evolving retail payment technologies? Evidence from Japan. Journal of the Japanese and International Economics, 49(May): 85-99. https://doi.org/10.1016/j.jjie.2018.05.001

Fung, B. - Huynh, K.P. - Stuber, G. (2015): The Use of Cash in Canada. Bank of Canada Review, Spring, pp. 45-56.

G4S (2018): World Cash Report. https://www.g4scashreport.com/. Downloaded: 13 September 2019.

Greene, C. - Stavins, J. (2018): The 2016 and 2017 Surveys of Consumer Payment Choice: Summary Results. Fed Boston Research Data Reports, No. 18-3, May.

Greenham, T. - Travers-Smith, F. (2019): Cashing Out: the hidden costs and consequences of moving to a cashless society. RSA Report, January. https://www.thersa.org/globalassets/ pdfs/reports/rsa-cashing-out.pdf. Downloaded: 13 September 2019.

Guérin, I. - Lanos, Y. - Michiels, S. - Nordman, C.J. - Venkatasubramanian, G. (2017): Demonetisation, Social Networks and Social Protection: Insights from Rural Tamil Nadu. IRD Working Papers 2017/10, October.

Ilyés, T. - Varga, L. (2015): Show me how you pay and I will tell you who you are - Sociodemographic determinants of payment habits. Financial and Economic Review, 14(2): 25-61. https://en-hitelintezetiszemle.mnb.hu/letoltes/2-ilyes-varga-en.pdf

Immordino, G. - Russo, F.F. (2018): Cashless payments and tax evasion. European Journal of Political Economy, 55(November): 36-43. https://doi.org/10.1016/j.ejpoleco.2017.11.001

Jobst, C. - Stix, H. (2017): Is cash back? Assessing the recent increase in cash demand. SUERF Policy Note, Issue No. 19, October.

John, S. (2019): Less-cash, but not cashless. Lecture: Currency Conference, Dubai, April 7-11. https://www.bankofengland.co.uk/-/media/boe/files/speech/2019/less-cash-butnot-cashless-speech-by-sarah-john. Downloaded: 13 September 2019.

Jonker, N. - Hernandez, L. - de Vree, R. - Zwaan, P. (2018): From cash to cards: how debit card payments overtook cash in the Netherlands. DNB Occasional Studies, Volume 16-1, January.

Judson, R. (2017): The Death of Cash? Not So Fast: Demand for U.S. Currency at Home and Abroad, 1990-2016. Lecture: International Cash Conference 2017, Mainau, April 25-27. 
Kangas, J. (2019): How can we (not) estimate the cash usage in Finland? Lecture: Future of Cash Conference, Athens, February 19-21.

Khan, J. - Belk, R.W. - Craig-Lees, M. (2015): Measuring consumer perceptions of payment mode. Journal of Economic Psychology, 47(January): 37-49. https://doi.org/10.1016/j. joep.2015.01.006

Khiaonarong, T. - Humphrey, D. (2019): Cash Use Across Countries and the Demand for Central Bank Digital Currency. IMF Working Paper 19/46, March. https://doi. org/10.5089/9781484399606.001

Lalouette, L. - Esselink, H. (2018): Trends and developments in the use of euro cash over the past ten years. ECB Economic Bulletin, Issue 6, pp. 87-109.

Lybek, T. - Dybczak, K. (2019): Hungary Selected Issues. IMF Country Report No. 19/358, December. https://doi.org/10.5089/9781513521435.002

Mancini-Griffoli, T. - Peria, M.S.M. - Agur, I. - Ari, A. - Kiff, J. - Popescu, A. - Rochon, C. (2018): Casting Light on Central Bank Digital Currency. IMF Staff Discussion Note 18/08, November. https://doi.org/10.5089/9781484384572.006

Miller, C. (2017): Addressing the limitations of forecasting banknote demand. Lecture: International Cash Conference 2017, Mainau, April 25-27. https://www.bankofengland. co.uk/-/media/boe/files/paper/2017/addressing-the-limitations-of-forecasting-banknotedemand. Downloaded: 10 January 2020.

MNB (2017): Financial savings of households based on micro- and macro-statistical data. 2017 Magyar Nemzeti Bank. https://www.mnb.hu/letoltes/ha-ztarta-sok-eng.PDF. Downloaded: 13 December 2019.

MNB (2019a): Payment Systems Report. July 2019 Magyar Nemzeti Bank. https://www. mnb.hu/letoltes/mnb-payment-systems-report-2019-digitalis-final.pdf. Downloaded: 13 September 2019.

MNB (2019b): Household Finance and Consumption Survey “What Do We Live From?" 2017 Presentation of the first results for Hungary. 2019 Magyar Nemzeti Bank. https://www. mnb.hu/letoltes/vagyonfelmeres-2017-web-en.pdf. Downloaded: 13 December 2019.

NBP (2015): Household Wealth and Debt in Poland - Pilot survey report 2014. 2015. https:// www.nbp.pl/en/publikacje/inne/bzgd/bzgd_2014_en.pdf. Downloaded: 13 December 2019.

NBP (2017): Household Wealth and Debt in Poland - Report of 2016 survey. 2017. https:// www.nbp.pl/en/publikacje/inne/bzgd/bzgd_2016_en.pdf. Downloaded: 13 December 2019. 
Perkins, D.W. (2019): The Potential Decline of Cash Usage and Related Implications. CRS Reports, May. https://crsreports.congress.gov/product/pdf/R/R45716. Downloaded: 13 September 2019.

Politronacci, E. - Ninlias, E. - Palazzeschi, E. - Torre, G. (2017): The demand for cash in France: Review of evidence. Lecture: International Cash Conference 2017, Mainau, April 25-27. https://www.bundesbank.de/resource/blob/634956/\%20 906da37dde344bf1a77dd4ca717a4bc0/mL/2017-06-19-politronacci-data.pdf. Downloaded: 13 September 2019.

Politronacci, E. - Moret, A. - Bounie, D. - Francois, A. (2018): Use of cash in France: The payment method of choice for low-value purchases. Banque de France Bulletin, No. 220/2, December.

Reserve Bank of India (2017): Annual Report 2016-2017. https://rbidocs.rbi.org.in/rdocs/ AnnualReport/PDFs/RBIAR201617_FE1DA2F97D61249B1B21C4EA66250841F.PDF. Downloaded: 13 September 2019.

Rogoff, K. (2016): The Curse of Cash. Princeton University Press, Princeton, NJ, USA. https:// doi.org/10.1515/9781400883219

Schweizerische Nationalbank (2018): Survey on payment methods 2017. https://www.snb.ch/ en/mmr/reference/paytrans_survey_report_2017/source/paytrans_survey_report_2017. en.pdf. Downloaded: 13 September 2019.

Seitz, F. - Reimers, H.-E. - Schneider, F. (2018): Cash in Circulation and the Shadow Economy: An Empirical Investigation for Euro Area Countries and Beyond. CESifo Working Papers 7143, July.

Shirai, S. - Sugandi, E.A. (2019): Growing Global Demand for Cash. International Business Research, Vol. 12., No. 12. https://doi.org/10.5539/ibr.v12n12p74

Sisak, B. (2011): What drives cash demand? Transactional and residual cash demand in selected countries. MNB Working Papers 2011/10.

Skingsley, C. (2018): Considerations for a cashless future. Lecture: SNS Finance Panel, Stockholm, 22 November 2018. https://www.riksbank.se/globalassets/media/tal/ engelska/skingsley/2018/skingsley_considerations-for-a-cashless-future.pdf. Downloaded: 13 September 2019.

Smestad, V.G. (2017): Danish households opt out of cash payments. Danmarks Nationalbank Analysis No. 24, December.

Söderberg, G. (2018): What is money and what type of money would an e-krona be? Sveriges Riksbank Economic Review, 2018:3, pp. 17-28. 
Stavins, J. (2018): Consumer preferences for payment methods: Role of discounts and surcharges. Journal of Banking \& Finance, 94(June): 35-53. https://doi.org/10.1016/j. jbankfin.2018.06.013

Sumner, S.B. (1990): The transactions and hoarding demand for currency. Quarterly Review of Economics and Business, 30(March): 75-89.

Végső, T. - Belházyné Illés, Á. - Bódi-Schubert, A. (2018): Készpénz vagy kártya? A magyar lakosság fizetési szokásainak feltáró elemzése (Cash or Card? An Explorative Analysis of Consumers' Payment Behaviour in Hungary). Pénzügyi Szemle (Public Finance Quarterly), 63(4): 455-479.

Wright, R. - Tekin, E. - Topalli, V. - McClellan, C. - Dickinson, T. - Rosenfeld, R. (2017): Less Cash, Less Crime: Evidence from the Electronic Benefit Transfer Program. NBER Working Paper No. 19996, March. https://doi.org/10.1086/693745

Zhang, L. - Brooks, R. - Ding, D. - Ding, H. - He, H. - Lu, J. - Mano, R. (2018): China's High Savings: Drivers, Prospects, and Policies. IMF Working Paper 18/277, December. https:// doi.org/10.5089/9781484388778.001 